\title{
CORRIGENDUM
}

\section{Experimental study of the mean structure and quasi-conical scaling of a swept-compression-ramp interaction at Mach 2 - CORRIGENDUM}

doi:10.1017/jfm.2018.8, Published by Cambridge University Press,

19 February 2018

In the original published article Vanstone et al. (2018) the author Mustafa Nail Musta's name was misspelled as Mastafa Nail Musta.

The error has been rectified in the online PDF and HTML versions.

\section{REFERENCE}

Vanstone, L., Musta, M. N., Seckin, S. \& Clemens, N. 2018 Experimental study of the mean structure and quasi-conical scaling of a swept-compression-ramp interaction at Mach 2. J. Fluid Mech. 841, 1-27. 